\title{
Affording Employee Voice: How Enterprise Social Networking Sites (ESNS) Create New Pathways for Employee Expression
}

\author{
Pamela Estell \\ Communication \& Information Sciences \\ University of Hawai'i at Manoa \\ pestell@hawaii.edu
}

\author{
Elizabeth Davidson \\ Shidler College of Business \\ University of Hawai'i Mānoa \\ edavidso@hawaii.edu
}

\author{
Kaveh Abhari \\ Fowler College of Business \\ San Diego State University \\ kabhari@sdsu.edu
}

\begin{abstract}
As organizations seek to find new ways to engage employees and increase workplace participation, many have turned to Enterprise Social Networking Sites (ESNS) as a tool to foster dialogue and participation. Seeking to capitalize on social technologies that have enjoyed a warm reception in the personal lives of many of their employees, organizations hope to harness the accessibility and immediacy of these platforms to encourage tasks such as knowledge management, training, and direct communication at work. Employees, accustomed to using social media tools outside of work, are also leveraging these channels to express their voice within organizations. In this paper, we develop the concept of ESNS voicing affordances that enable employees to individually and directly express their voice within their organizations. Drawing from a detailed review of relevant literature on employee voice and social media affordances, we follow a systematic scale development process to establish an instrument for the construct of ESNS voicing affordances.
\end{abstract}

\section{Introduction}

Businesses are increasingly turning to social media tools at work to foster employee participation and engagement. Managers see the potential to leverage social media tools for knowledge management and overall productivity [27][26], and platform vendors now market a variety of Enterprise Social Networking Sites (ESNS), or social media specifically for (and bounded within) organizations [29]. Employees are utilizing these technologies not only to share taskrelated knowledge but also to voice their ideas and opinions to and about their employers. Publicly reported incidents have illustrated potential benefits and drawbacks of doing so in the workplace, for both employees and employers. For instance, a highly publicized "anti-diversity manifesto" written by a Google engineer and posted internally left both the employee and organization not only embarrassed, but entrenched in a protracted legal battle that is still ongoing [48]. More recently, an Amazon VP quit in protest after several employees were fired for voicing concerns-including organizing protests and circulating petitions on internal email lists-about how warehouse workers have been treated in the midst of the COVID-19 pandemic [49].

Such incidents highlight the need to better understand when, why and how employees express their voice via organizational social media channels. Hirschman's seminal book on voice and exiting (1970) defines employee voice as individually or collectively seeking a change in an objectionable state through the use of voice practices. Subsequently, employee voice has been studied in the Human Resource Management, Employee Relations, and Organizational Behavior fields [38], and recently in the Public Relations literature [43]. Employees and employers have adopted various forms of employee voice mechanisms, many of which overlap between formal channels (such as grievance procedures and trade union representation) and informal structures such as open-door policies [9]. As general notions of workplace democracy have evolved, employees have now come to expect to have a voice [9] and perceive themselves as capable of advocating on their own behalf [20]. From the employer's perspective, encouraging employee voice may stimulate employee participation and engagement [20][24], and subsequently employee satisfaction, including reducing turnover intention [3].

The notion of the everyday citizen having a "voice" is no more apparent than in the advent and proliferation of social media [2]. A growing body of literature is addressing the potential for knowledge management and collaboration through ESNS [11][22][27][28] [26]. However, the potential of ESNS as a channel for employee voice and engagement has yet to be explored in research. This paper draws from the relevant literatures to elaborate the concept of employee voicing through ESNS, to develop the 
construct perceived ENSN voicing affordances, and to develop a new measurement instrument for studying this phenomenon.

\section{Background}

Research in fields such as human resources, communication, and organizational behavior (including public relations) provides important insights on employee voicing behaviors. The following literature review examines each of these areas to outline the employee voice construct. It also examines information systems literature on social media affordances, which is relevant to understanding employee voicing affordances in ESNS.

\subsection{Conceptualizing Employee Voice}

Noted business scholar Hirschman (1970) defined employee voice as:

any attempt at all to change, rather than to escape from, an objectionable state of affairs, whether through individual or collective petition to the management directly in charge, through appeal to a higher authority with the intention of forcing a change in management, or through various types of actions or protests, including those that are meant to mobilize public opinion. (p. 30)

While his Exit-Voice-Loyalty theory initially referred to customers, it has since been applied more broadly to employees by researchers investigating voice from a variety of disciplinary perspectives [38]. Consensus on how to define the voice construct across fields has not been reached to date.

2.1.1 Categorizing Voicing Behaviors. Since Hirschman's (1970) initial work, scholarship on employee voicing has developed along two major dimensions: human resources and employee relations scholars have addressed voicing from a dissatisfaction and grievance-oriented perspective, while organizational behavioral scholars have focused on the prosocial aspects of employee voice, including participation and extra-role behaviors [38]. Following these research streams, voicing behaviors may be categorized in two distinct (yet at times overlapping) dimensions: promotive voice and prohibitive voice [31][4]. Promotive voice is concerned with prosocial and extra-role behaviors, while prohibitive voice is more critical and grievance-oriented. Employees may engage in both types of voicing behaviors under different circumstances, motivated by different goals, including the desire to participate in decision making, express dissatisfaction, improve organizational or unit functioning, and communicate different points of view (to name a few) [36].

2.1.2 Rationales for Employee Voice. The idea of grievance expression in the HRM/ER literature builds on the idea of 'principled organizational dissent' studied early on by [16]. Principled organizational dissent examines how individuals in the workplace protest and/or attempt to change the organizational status quo due to objections over current policy or practice and the mechanisms individuals use in making their protest. More recent studies on dissent, such as [44], highlight the need for employees to have the opportunity to voice dissent, arguing that employees can reclaim their identities by doing so. The authors posit that by dissenting, individuals voice their conscience, recover their dignity, and lay claim to their principles and self-worth. Dissenting, or sounding the alarm on concerns of ethic or the general status quo, complement research on whistleblowing, or disclosing (using voice) to organizational members about perceived wrongdoing so that management can act [39]. Although dissent, in general, has been categorized as a prohibitive voicing behavior, as contemporary firms grapple with their role in relevant social and political issues, employee activism is emerging as a nuanced form of dissent, aimed specifically at influencing the way organizations engage with current social and political issues [51].

In the organizational behavior literature, employee voice is seen as a prosocial practice that is otheroriented (e.g. focused on the positive well-being of the organization). From this perspective employees use prosocial voice as a means to go above and beyond job duties to the benefit of the organization and to engage with their firms. Recent studies indicate that as employees become more engaged in their firms, they are more likely to voice [4]. Van Dyne \& LePine (1998) argue that voice as an extra role behavior is both positive and discretionary. As a proactive, promotive, and challenging behavior, they view voicing as a functional behavior that emphasizes expression of constructive challenges intended to improve an organization rather than merely criticize [47]. Voice as a prosocial tool aids in advocacy participation, or constructive and proactive behaviors, like voicing high standards, challenging others, or making suggestions for change [46].

2.1.3 Organizational voicing channels. How employees express voice varies within organizations, and may depend on the formality of the voicing occasion. Formal and indirect voice has historically 
been the primary method by which employees choose to voice messages to upper management. Gomez et al. (2010, p. 401) define "'formal' voice as any institutionalized form of two-way communication between management and employees." The 2011 Involvement and Participation Association report also recognized the concepts of formal and informal voice by pointing out that "voice can take many forms and is generally grouped into direct and indirect voice" [50]. Lewin (2014) noted that employee voice has evolved from a system largely dependent on unionized and grievance management (formal, indirect), to more direct and informal (non-unionized) alternative dispute resolutions, such as engaging employees in problem-focused task forces. This is in part due to the decline of trade unions in the U.S. and elsewhere [20].

To summarize, employee voice can be understood as a multidimensional construct (promotive or prohibitive, formal or informal, direct or indirect), and employee voicing behaviors may reflect employees' grievances, dissatisfaction, advocacy or even protest, on the one hand, or their desire to engage with and promote the organization on the other. Today, employees have different options to voice via various organizational communication channels, including in recent years, Enterprise Social Networking Sites (ESNS). Whether and how employee voicing behaviors manifest via ESNS have yet to be investigated systematically in scholarly research.

\subsection{ESNS and Employee Voice}

As many organizations have already, or are in the process of implementing ESNS to support knowledge management and internal communication [8][33][26], it is important to understand the ways in which social media affordances may be leveraged within the firm. These Information and Communication Technologies (ICTs) present communicative channels within organizations [7][40] that may increase opportunities for direct voice expression by employees. ESNS are similar to personal social media channels in that they provide access to personal information, connections, and opportunities to post original content or share content from others. Unlike personal social media channels, however, ESNS, are sanctioned by organizational management and bounded within the firm [10]. Thus, acceptable use practices and expression may differ substantively from social media for personal use. Employee voicing via ESNS may be beneficial to employees and employers, as noted above, but may also contribute to human resource and public relations concerns. As such, it is important that researchers and practitioners understand how motivations to voice may be related to (and potentially influenced by) the presence of ICTs such as ESNS.

2.2.1 Social Media Affordances. Many researchers have approached the study of ICTs for communicative purposes from an affordance perspective. Affordance is a term used to refer to objects (more contemporarily, technological systems) that enable multiple users to interact with the same object in different ways, for different actions, and sometimes with different results. Initially conceptualized by an ecological psychologist, Gibson defined affordances as, "latent cues in environments, such as substances, surfaces, objects, and places, that hold possibilities for action" [14, $\mathrm{p}$. 279]. He argued that actors view objects not solely for what they are, but for the types of uses they afford.

Table 1 (below) gives examples of general social media affordances that have been proposed in various literatures [23].

Table 1. Social Media Affordances

\begin{tabular}{|l|l|}
\hline Affordance & Description \\
\hline Self-Presentation & $\begin{array}{l}\text { Enables users to present } \\
\text { information related to } \\
\text { themselves. }\end{array}$ \\
\hline Content Sharing & $\begin{array}{l}\text { Enables users to share } \\
\text { content unrelated to } \\
\text { themselves. }\end{array}$ \\
\hline Relationship Formation & $\begin{array}{l}\text { Enables users to form } \\
\text { relationships with others. }\end{array}$ \\
\hline Group Management & $\begin{array}{l}\text { Enables users to form } \\
\text { online groups and } \\
\text { communities. }\end{array}$ \\
\hline Browsing Others' Content & $\begin{array}{l}\text { Enables users to view } \\
\text { content provided by } \\
\text { others. }\end{array}$ \\
\hline Meta-voicing & $\begin{array}{l}\text { Enables users to react } \\
\text { online to others' content } \\
\text { and activities. }\end{array}$ \\
\hline Communication & $\begin{array}{l}\text { Enables users to directly } \\
\text { communicate with one } \\
\text { another. }\end{array}$ \\
\hline Collaboration & $\begin{array}{l}\text { Enables users to } \\
\text { collaborate with each } \\
\text { other online. }\end{array}$ \\
\hline
\end{tabular}

The affordance concept has been used by researchers in fields such as information systems [25], education [32], knowledge management [13][34] and (extensively) in social media [26], to understand how ICT artifacts (i.e., social media platforms) come to be understood and used in organizations, and the varied outcomes that may result. Treem and Leonardi (2013) comment, "Scholars who study the relationship between new technologies and social practices have found great utility in the affordance concept because it 
helps to explain why people using the same technology may engage in similar or disparate communication and work practices" (p. 146).

2.2.2 Employee Voicing Affordances. As the affordance concept has become more widely adopted and applied, scholars have used the idea of general affordances to examine employee interaction on social media sites within businesses and for various practices. Identifying these types of general affordances is a useful start to investigating how employees use social media at work. However, such generalized affordance categories (see Table 1) represent a "lowest common denominator" approach to investigating how employees perceive the actions that ESNS features and functions afford, and thus they do not address voicing behaviors and actions specifically. There is of course some overlap in how individuals perceive and actualize social media affordances in different practices. For instance, an employee might recognize the opportunity for content sharing by making a post to an ESNS discussion stream. This general affordance may then relate to the employee's goals and intended actions for sharing knowledge with others in the firm, participating in a team effort, or voicing a stance on organizational strategy or management actions (i.e., a voicing behavior).

To more fully explore employee voicing affordances in ESNS, differences in the goals and intended actions of individuals who engage on ESNS for communication purposes must be considered, and more specifically, targeted affordance categories identified. However, there is no consensus on how to identify and observe affordances [12]. Some researchers prefer broad, macro-level concepts (such as those in Table 1), which may be difficult to assess meaningfully with regard to specific actions and practices. Others favor a more contextualized approach to identifying and observing affordances, often derived from particular studies of work or organizational settings, which are then less generally applicable across settings and practices [1][35].

In our study, we adopt a middle path between these two approaches to conceptualize affordances that are relevant to employee voicing practices in particular but that may occur across organizational settings and work contexts. The literature on employee voicing (Section 2.1) highlights the theoretical and conceptual contours for employee voicing behaviors and actions, including employee goals and motivations ranging from promotive to prohibitive to advocacy or protest, informal as well as formal channels, and direct as well as indirect voicing behaviors. This conceptual outline then allows us to develop a measurement instrument that can capture valuable insights into a general category of communication affordances, i.e., employee voicing affordances, using traditional construct and quantitative measurement development methods [12].

\section{Research Design \& Methods}

The goal of this paper is to develop the concept of employee voicing through ESNS and a measurement instrument for these affordances that can support research into employee voicing practices and consequences. To contextualize this concept and measurement instrument, we were also interested in how employees view ESNS as possible communication channels to express their voice and whether they are likely to do so. To collect data for these purposes, we conducted a cross-sectional survey of individuals who work in organizations and have opportunities to use ESNS at work. The questionnaire relied on self-report, perceptual data of voicing behaviors within the organization, and individual perspectives on using ESNS affordances for voicing.

\subsection{Measurement Model Specification and Instrument Design}

We developed our initial operational definition and measurement items for employee voicing affordances by adapting existing voicing scales [47] and previously studied perceived social media affordances [23]. The initial pool of items included 43 items in 7 groups. We pre-tested the instrument in two phases. In the first phase, measurement items and their categorization were pre-tested through card-sorting, following established guidelines [37]. In the second phase, the refined measurement items were developed into a questionnaire and pre-tested for flow, structure, format and language.

The card sorting exercise was conducted by judges, selected based on their role within an organization that uses some form of ESNS. This technique was useful in testing the initial relationships between different items. Card sorting was also an initial attempt to test face validity by grouping items into different categories, thus confirming the conceptualization of affordances such as promotive, prohibitive and advocacy voicing affordances.

During the card-sorting exercise, randomly listed items, along with the names and definitions of the constructs, were distributed to the judges. The judges individually (1) sorted each item to what they believed 
to be the most appropriate construct, or (2) marked it as "Does not fit any category", or "Does not make sense or is confusing." Twelve items marked as "does not fit any category" or "does not make sense or is confusing" were refined or removed before the full questionnaire was developed.

In the second phase, the refined measurement items were included in a questionnaire that examined voicing behaviors, and ESNS affordances. All items in the questionnaire were constructed as 7-point Likert-type scale questions [21] to avoid collapsed variance and maintain the consistency of responses. The questions were ordered randomly to avoid possible order effects [6]. An expert panel reviewed the questionnaire to identify flaws associated with questionnaire construction, wording, and formatting. The questionnaire was evaluated in terms of respondent issues (e.g., comprehension, burden), as well as format issues (e.g., flow, typographical errors, and order effects). The final questionnaire includes 12 items related to voicing affordances.

\subsection{Survey Data Collection}

To validate the measurement instrument for employee voicing affordances, and to ensure that the scales demonstrated the appropriate levels of reliability and validity, we conducted a cross-sectional survey. The subjects for this study were drawn from a convenience sample of individuals who currently use some form of ESNS as part of their work role. Invitations to participate in the survey were extended via direct and group email to relevant populations, as well as LinkedIn-a professional social networking platform. Participants included professionals in a variety of firms including academic, technology, entertainment, and service industry organizations. The goal was to gather sufficient, variable data to evaluate the measurement instrument, not to represent a specific population. The questionnaire was administered using email and the LinkedIn community (a social networking site geared toward career professionals) and data were collected online using Qualtrics survey software. Respondents were also asked to provide feedback on the items, format, and scaling.

Of the 77 individuals who responded, thirty-six responses were removed due to incomplete data, leaving a final sample of 41 usable responses for analysis. Since the data was normally distributed, this sample size is a reasonable number for multivariate analysis [17]. The sample was relatively balanced according to all known demographic factors. Survey participants were predominately from the western
United States and had a minimum of at least 5 years of professional work experience. Although respondents reported using a variety of ESNS at work (see Figure 1 ), the majority indicated the use of Slack or Google Suite applications for ESNS purposes. Additionally, respondents had a mean intention to use ESNS for voicing purposes of 5.4, and a standard deviation of 1.3

\section{Figure 1.Respondent report of ESNS platforms use}

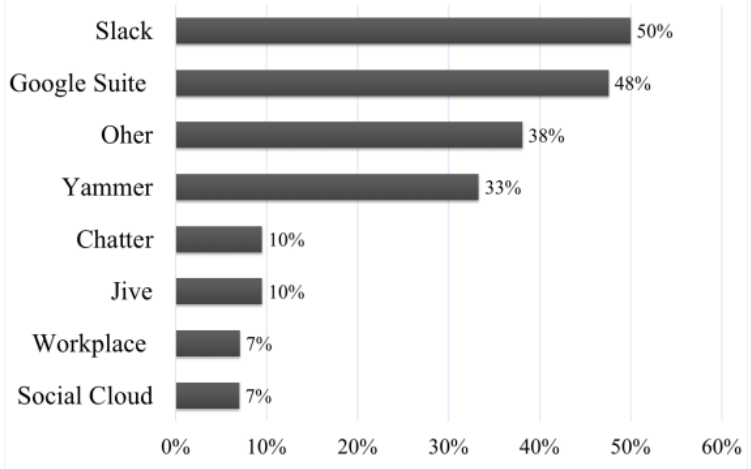

We were also interested in how respondents perceived ESNS as a communication channel for voicing within their work setting. Figure 2 reports the mean and standard deviation of survey respondents' intentions to use ESNS at their work place for voicing. Overall, in this sample, respondents indicated they were likely to use ESNS for various voicing actions.

\section{Figure 2. Respondents' Intention to use ESNS}

When working in an organization with ESNS I intend to...

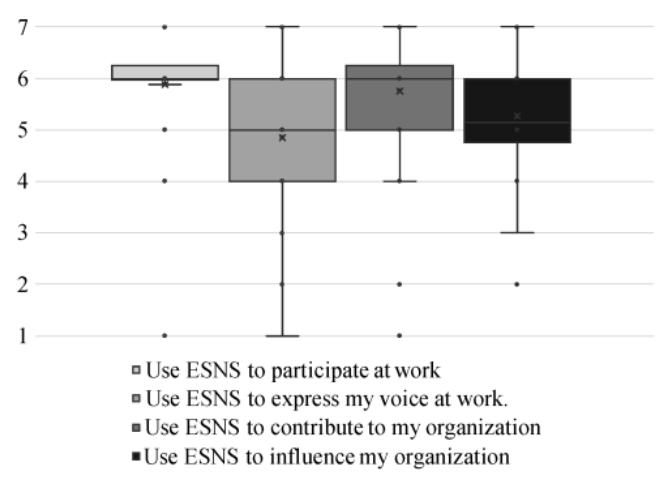

Figure 3 reports survey respondents' assessment of how typical ESNS features might be useful in their voicing behaviors. Interestingly, communication features like group chats and direct messaging were most often identified as useful for voicing, whereas social media networking features such as creating a 
profile, following others, and "liking" content were less commonly identified with voicing. (These latter features seem to be typical of private voicing actions.)

\section{Figure 3. Respondent report of useful features}

Number of Respondents Rating ESNS Features as Moderately to Extremely Useful for Voicing

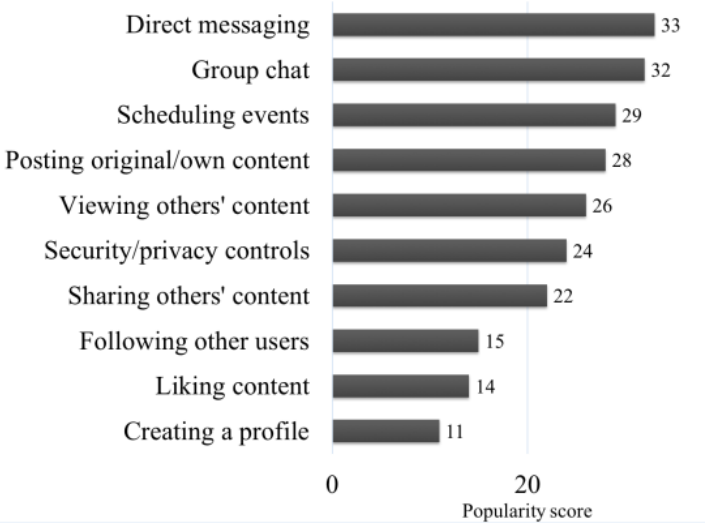

These descriptive items illustrate that employees do have intentions to voice via ESNS, and they perceive various ESNS features as possibly supporting their voicing actions. The remainder of our data collection and analysis is directed at identifying and characterizing the dimensions of employee voicing affordances that link motivations or intentions to voice with specific features that might be employed to do so.

3.2.1 Exploratory Factor Analysis of voicing affordance dimensions. We ran an exploratory factor analysis (EFA) to check the dimensionality of the proposed voicing constructs. We used Maximum Likelihood with Varimax rotation to investigate the relative importance of each item. Varimax rotation was used to preserve the unique variance of each measure, achieve more generalizable results, and render a more optimum solution [5] [41]. The result shows that the Kaiser-Meyer-Olkin measure of sampling adequacy is 0.656 (above the recommended value of 0.6) and that Bartlett's test of Sphericity is significant $\left(\chi^{2}=198, p<0.00\right)$ indicating that the correlations between items are sufficient for EFA [17].

After removing the poor performing items, the final rotation matrix suggests a three-factor solution with 12 items. An examination of the eigenvalues reveals that these three components with eigenvalues greater than 1 explain $67 \%$ of the variance in total. We adopted the three-component solution because of the theoretical support, the "leveling off" of eigenvalues on the screen plot after three factors, and the insufficient number of primary loadings for any subsequent factors. We retained items that have factor loadings higher than 0.4 $( \pm 0.30=$ minimal, $\pm 0.40=$ important, $\pm .50=$ practically significant; [17]). Overall, these analyses reveal three distinct dimensions for employee voicing in ESNS channels: perceived promotive, prohibitive, and advocacy affordances.

3.2.2 Confirmatory Factor Analysis. In addition, we ran a confirmatory analysis in order to assess the reliability and validity of the three identified dimensions. We used SmartPLS 3 [42] to conduct this test. Tables 2 and 3 present the overall quality of the measurement items for the three first-order reflective constructs. As presented in Table 2, all constructs were found to have good to very good factor loading (above 0.7). Internal consistency reliability (construct reliability) was assessed by examining the Composite Reliability (CR) and Cronbach's alpha of the constructs. Each measurement met the reliability criteria [18].

Table 2 Factor loadings

\begin{tabular}{llll}
\hline & PRM & PRH & ADV \\
\hline PRM1 & 0.804 & \\
\hline PRM2 & 0.802 & \\
\hline PRM3 & 0.730 & \\
\hline PRM4 & 0.892 & \\
\hline PRM5 & 0.859 & & \\
\hline PRH1 & & \\
\hline PRH2 & 0.700 & \\
\hline PRH3 & 0.855 & 0.758 \\
\hline PRH4 & 0.767 & 0.750 \\
\hline ADV1 & & 0.741 \\
\hline ADV2 & & \\
\hline ADV3 & & \\
\hline
\end{tabular}

Table 3. Internal consistency reliability

\begin{tabular}{lcccc}
\hline & AVE & $\begin{array}{c}\text { Composite } \\
\text { Reliability }\end{array}$ & $\begin{array}{c}\text { Cronbach's } \\
\text { Alpha }\end{array}$ & VIF \\
\hline PRM & 0.671 & 0.910 & 0.876 & 1.215 \\
\hline PRH & 0.594 & 0.854 & 0.775 & 1.458 \\
\hline ADV & 0.615 & 0.827 & 0.707 & 1.231 \\
\hline
\end{tabular}

3.2.3 Construct Validity Convergent validity of each dimension was tested by examining Average Variance Extracted (AVE). All dimensions met the threshold of 0.5 (Table 3). Multicollinearity among indicators was also calculated for the constructs by computing the Variance Inflation Factor (VIF) of each indicator. All computed VIF values are well below the threshold of 5.0, suggesting that multicollinearity is not a threat to the validity of the study's findings (Table 3). Moreover, all the pathological VIFs resulting from the 
full collinearity test were lower than 5. Discriminant validity was tested by the Fornell-Larcker criterion and the examination of cross-loadings. Comparing the loadings indicated that an item's loadings in its own construct are in all cases higher than all of its cross loadings with other constructs. Additionally, the AVE of each construct was higher than the construct's highest squared correlation with any other construct [17][18]. The HTMT (Heterotrait-Monotrait) ratio of correlations values was also below 0.90 . The results of these tests indicate adequate discriminant validity.

Table4. Discriminant validity, Fomell-Larcker criterion

\begin{tabular}{llll}
\hline & ADV & PRH & PRM \\
\hline ADV & $\mathbf{0 . 7 8 4}$ & & \\
\hline PRH & 0.420 & $\mathbf{0 . 7 7 1}$ & \\
\hline PRM & 0.156 & 0.432 & $\mathbf{0 . 8 1 9}$ \\
\hline
\end{tabular}

The main contribution of our study is the following measurement instrument that can be used for assessing employees' perceived voicing affordances in ESNS (presented in Table 5).

Table 5. Final Scale

\begin{tabular}{|c|c|}
\hline $\begin{array}{l}\text { First-order } \\
\text { formative } \\
\text { dimensions }\end{array}$ & Items \\
\hline \multirow{6}{*}{$\begin{array}{l}\text { Promotive } \\
\text { Voicing } \\
\text { Affordances }\end{array}$} & ESNS allows me to ... \\
\hline & $\begin{array}{l}\text { PRM1: participate in problem solving at } \\
\text { work }\end{array}$ \\
\hline & $\begin{array}{l}\text { PRM2: share my ideas to help the } \\
\text { organization }\end{array}$ \\
\hline & PRM3: voice constructive suggestions \\
\hline & $\begin{array}{l}\text { PRM4: suggest new project strategies or } \\
\text { actions }\end{array}$ \\
\hline & PRM5: share my expertise to help others \\
\hline \multirow{5}{*}{$\begin{array}{l}\text { Prohibitive } \\
\text { Voicing } \\
\text { Affordances }\end{array}$} & ESNS allows me to ... \\
\hline & $\begin{array}{l}\text { PRH1: point out problems about work } \\
\text { related processes }\end{array}$ \\
\hline & $\begin{array}{l}\text { PRH2: give feedback on policies or } \\
\text { procedures }\end{array}$ \\
\hline & PRH3: influence work-related decisions \\
\hline & $\begin{array}{l}\text { PRH4: speak up to managers about } \\
\text { employee needs }\end{array}$ \\
\hline \multirow{4}{*}{$\begin{array}{l}\text { Advocacy } \\
\text { Affordances }\end{array}$} & ESNS allows me to ... \\
\hline & $\begin{array}{l}\text { ADV1: tell my employer my stance on social } \\
\text { or political issues }\end{array}$ \\
\hline & $\begin{array}{l}\text { ADV2: speak up to my employer about } \\
\text { issues that impact society }\end{array}$ \\
\hline & $\begin{array}{l}\text { ADV3: communicate my opinions about } \\
\text { management actions }\end{array}$ \\
\hline
\end{tabular}

\section{Discussion \& Contributions}

In this paper, we develop the concept of ESNS voicing affordances that enable employees to individually and directly express their voice within their organizations. Drawing from a detailed review of relevant literature on employee voice and social media affordances, we followed a systematic scale development process to establish an instrument for the construct of voicing affordances through ESNS. The results of the survey study indicate three distinctive, formative dimensions for employee voicing affordances - promotive, prohibitive, and advocacy. We operationalize ESNS employee voicing affordances as a first-order formative construct and demonstrate satisfactory reliability and validity of the instrument. The final result is a reliable, yet simple instrument with 12 items (see Table 5). This study thus demonstrates how quantitative measurements can be developed to examine sociotechnical phenomena from an affordance perspective [12].

The employee voicing affordance (in ESNS) construct and measurement instrument developed in this study offers several contributions. First, this instrument highlights conceptually how employees perceive ESNS voicing affordances. This extends research interest on ESNS beyond often-studied uses for knowledge management to consider employee voicing behaviors along three dimensions of voicing action (promotive, prohibitive, and advocacy). These dimensions are evident in research and theorizing on voicing in diverse academic fields, but have not been brought together analytically as a theoretical construct (employee voicing behaviors).

This study provides a resource for researchers to draw on when exploring voicing behavior on ICTs in an organizational context. The measurement instrument developed here can assist in evaluating platform affordances for voicing to investigate individuals' behaviors and motivations to voice via ESNS. This may then extend the Needs-Affordances-Features (NAF) framework [23] for social media affordances to support research to examine how specific psychological motivations influence these three dimensions in driving voicing behavior on ESNS, and the role affordances play in creating opportunities to voice within an organization. Such research can also consider contextual influences such as organizational voicing climate, which may promote or hinder employee voicing behavior even when ESNS are present.

A key benefit of this measurement instrument, which relies on the notion of affordances, is that it is not 
limited to the feature set of any specific social technology and thus can be applied in studies involving different organizational ESNS. Employee voicing affordances could however be used to assess whether certain types of social media features are commonly associated with voicing affordances. For instance, do employees use the "like" or "follow" features to express agreement with others' voice (as we often see in personal uses of social media), or are these features used primarily for other purposes in ESNS rather than voicing?

Finally, this research may serve as a resource to practitioners who have already, or are contemplating the use of ESNS to encourage employee participation. This survey instrument can also help organizations evaluate the affordances of ICTs they use to facilitate employee communication and understand the factors that influence employees' voicing behaviors in a work context. Understanding the motivations, benefits, and consequences of ESNS for voicing behavior will lend insights into organizational policies that can help modern firms engage employees productively, while avoiding potential pitfalls.

\section{Limitations}

Although the development of this initial instrument has exciting potential for scholars and practitioners alike, we must note limitations and opportunities for further development. First, the sample size was relatively small. A larger sample population would add further reliability and validity to the instrument. Although a broadly applicable instrument is of great utility to promote research, there may be additional affordances not included within the scope of this model, which may be relevant to some voicing contexts. Thus, continued study and development of the employee voicing construct dimensions will be beneficial. Lastly, cumulative and comparative studies of a variety of ESNS platforms and organizational contexts are needed to further assess the generalizability of the scales.

\section{Conclusion}

Businesses today continue to seek new ways to encourage employee participation and engagement. As the landscape of organizational social media and ICTs continue to develop, interest in the voicing aspects of ESNS will be a critical avenue of research. As evidenced in recent and high-profile incidences of employee expression on internal ICT systems having swift and wide-reaching ramifications, employers and employees need to understand the benefits and drawbacks of leveraging such systems for employee communication. The proposed measurement scale contributes to the existing literature by extending the concept of affordances to voicing, and establishing a framework from which to measure voicing affordances on ESNS.

\section{References}

[1] K. Abhari, E. J. Davidson, and B. Xiao, "Co-innovation platform affordances: Developing a conceptual model and measurement instrument," Industrial Management \& Data Systems, vol. 117, no. 5, pp. 873-895, Jan. 2017, doi: 10.1108/IMDS-05-2016-0156.

[2] d. m. Boyd and N. B. Ellison, "Social Network Sites: Definition, History, and Scholarship," Journal of ComputerMediated Communication, vol. 13, no. 1, pp. 210-230, 2007, doi: 10.1111/j.1083-6101.2007.00393.x.

[3] E. R. Burris, J. R. Detert, and A. C. Romney, "Speaking Up vs. Being Heard: The Disagreement Around and Outcomes of Employee Voice," Organization Science, vol. 24, no. 1, pp. 22-38, Feb. 2013, doi: 10.1287/orsc. 1110.0732 .

[4] M. Chamberlin, D. W. Newton, and J. A. LePine, "A meta-analysis of empowerment and voice as transmitters of high-performance managerial practices to job performance," Journal of Organizational Behavior, vol. 39, no. 10, pp. 1296-1313, 2018, doi: 10.1002/job.2295.

[5] A. B. Costello and J. Osborne, "Best practices in exploratory factor analysis: four recommendations for getting the most from your analysis," Exploratory Factor Analysis, vol. 10, no. 7, p. 10, 2005.

[6] J. W. Creswell, Research Design: Qualitative, Quantitative, and Mixed Methods Approaches. Thousand Oaks, CA: Sage Publications, 2013.

[7] R. L. Daft and R. H. Lengel, "Organizational Information Requirements, Media Richness and Structural Design," Management Science, vol. 32, no. 5, pp. 554-571, May 1986.

[8] J. M. DiMicco, W. Geyer, D. R. Millen, C. Dugan, and B. Brownholtz, "People Sensemaking and Relationship Building on an Enterprise Social Network Site," 2009, pp. 1-10, doi: 10.1109/HICSS.2009.343.

[9] T. Dundon, A. Wilkinson, M. Marchington, and P. Ackers, "The management of voice in non-union organisations: managers' perspectives," Employee Relations, vol. 27, no. 3, pp. 307-319, Jun. 2005, doi: $10.1108 / 01425450510591620$.

[10] N. B. Ellison and d. boyd, "Sociality through Social Network Sites," in The Oxford Handbook of Internet Studies, W. H. Dutton, Ed. Oxford: Oxford University Press, 2013, pp. 151-172.

[11] N. B. Ellison, J. L. Gibbs, and M. S. Weber, "The Use of Enterprise Social Network Sites for Knowledge Sharing 
in Distributed Organizations: The Role of Organizational Affordances.," American Behavioral Scientist, vol. 59, no. 1, pp. 103-123, 2015.

[12] S. K. Evans, K. E. Pearce, J. Vitak, and J. W. Treem, "Explicating Affordances: A Conceptual Framework for Understanding Affordances in Communication Research," Journal of Computer-Mediated Communication, vol. 22, no. 1, pp. 35-52, 2017, doi: 10.1111/jcc4.12180.

[13] J. L. Gibbs, N. A. Rozaidi, and J. Eisenberg, "Overcoming the 'Ideology of Openness': Probing the Affordances of Social Media for Organizational Knowledge Sharing: Overcoming the "ideology of openness," Journal of Computer-Mediated Communication, vol. 19, no. 1, pp. 102-120, Oct. 2013, doi: 10.1111/jcc4.12034.

[14] J. Gibson, "The Ecological Approach to Visual Perception.," in James J. Gibson and the Psychology of Percption, New Haven; London: Yale University Press, 1989.

[15] R. Gomez, A. Bryson, and P. Willman, "Voice in the Wilderness? The Shift From Union to Non-Union Voice in Britain," The Oxford Handbook of Participation in Organizations, Feb. 2010, doi: 10.1093/oxfordhb/9780199207268.003.0016.

[16] J. W. Graham, Research in Organizational Behavior, vol. 8. Greenwhich, CT: JAI Press, 1986.

[17] J. F. Hair and R. E. Anderson, Multivariate Data Analysis. Prentice-Hall Higher Education, 2010.

[18] J. F. Hair, G. T. M. Hult, C. Ringle, and M. Sarstedt, A Primer on Partial Least Squares Structural Equation Modeling (PLS-SEM). Sage Publications, 2013.

[19] A. Hirschman, Exit, Voice, and Loyalty; responses to decline in firms, organizations, and states. Cambridge, Mass.: Harvard University Press, 1970.

[20] J. Hyman, Employee Voice and Participation: Contested Past, Troubled Present, Uncertain Future. Milton, UNITED KINGDOM: Routledge, 2018.

[21] S. Jamieson, "Likert scales: how to (ab)use them," Medical Education, vol. 38, no. 12, pp. 1217-1218, 2004, doi: 10.1111/j.1365-2929.2004.02012.x.

[22] G. C. Kane, "The evolutionary implications of social media for organizational knowledge management," Information and Organization, vol. 27, no. 1, pp. 37-46, Mar. 2017, doi: 10.1016/j.infoandorg.2017.01.001.

[23] E. Karahanna, Sean Xin Xu, Yan Xu, and N. (Andy) Zhang, "The Needs-Affordances-Features Perspective for the Use of Social Media," MIS Quarterly, vol. 42, no. 3, pp. 737-756, Sep. 2018, doi: 10.25300/MISQ/2018/11492.

[24] J. Kim, J. P. MacDuffie, and F. K. Pil, “Employee voice and organizational performance: Team versus representative influence," Human Relations, vol. 63, no. 3, pp. 371-394, Mar. 2010, doi: 10.1177/0018726709348936.

[25] D. E. Leidner, E. Gonzalez, and H. Koch, "An affordance perspective of enterprise social media and organizational socialization," The Journal of Strategic Information Systems, Apr. 2018, doi: 10.1016/j.jsis.2018.03.003.

[26] P. M. Leonardi and E. Vaast, "Social media and their affordances for organizing: A review and agenda for research," The Academy of Management Annals, vol. 11, no. 1 , pp. 150-188, 2017.

[27] P. M. Leonardi, "Social Media, Knowledge Sharing, and Innovation: Toward a Theory of Communication Visibility," Information Systems Research, vol. 25, no. 4, pp. 796-816, Dec. 2014, doi: 10.1287/isre.2014.0536.

[28] P. M. Leonardi, "The social media revolution: Sharing and learning in the age of leaky knowledge," Information and Organization, vol. 27, no. 1, pp. 47-59, Mar. 2017, doi: 10.1016/j.infoandorg.2017.01.004.

[29] P. M. Leonardi, M. Huysman, and C. Steinfield, "Enterprise Social Media: Definition, History, and Prospects for the Study of Social Technologies in Organizations," Journal of Computer-Mediated Communication, vol. 19, no. 1, pp. 1-19, Oct. 2013, doi: 10.1111/jcc4.12029.

[30] D. Lewin, Oxford Hanbook of Conflict Management in Organizations, 1st ed. Oxford: Oxford University Press, 2014.

[31] J. Liang, C. I. C. Farh, and J.-L. Farh, "Psychological Antecedents of Promotive and Prohibitive Voice: A TwoWave Examination," Academy of Management Journal, vol. 55, no. 1, pp. 71-73, Feb. 2012, doi: 10.5465/amj.2010.0176.

[32] A. M. Limperos, M. M. Buckner, R. Kaufmann, and B. N. Frisby, "Online teaching and technological affordances: An experimental investigation into the impact of modality and clarity on perceived and actual learning," Computers \& Education, vol. 83, pp. 1-9, Apr. 2015, doi: 10.1016/j.compedu.2014.12.015.

[33] G. Lombardi, Exploring Internal Communication: Towards Informed Employee Voice, 3rd ed. Routledge Ltd, 2017.

[34] A. Majchrzak, S. Faraj, G. C. Kane, and B. Azad, "The Contradictory Influence of Social Media Affordances on Online Communal Knowledge Sharing," Journal of Computer-Mediated Communication, vol. 19, no. 1, pp. 3855, Oct. 2013, doi: 10.1111/jcc4.12030.

[35] A. Malsbender, S. Hoffmann, and J. Becker, "Aligning Capabilities and Social Media Affordances for Open Innovation in Governments," Australasian Journal of Information Systems, vol. 18, no. 3, Art. no. 3, Nov. 2014, doi: 10.3127/ajis.v18i3.1100.

[36] S. J. Miles and W. G. Mangold, "Employee voice: Untapped resource or social media time bomb?," Business Horizons, vol. 57, no. 3, pp. 401-411, May 2014, doi: 10.1016/j.bushor.2013.12.011.

[37] G. C. Moore and I. Benbasat, "Development of an Instrument to Measure the Perceptions of Adopting an Information Technology Innovation," Information Systems 
Research, vol. 2, no. 3, pp. 192-222, Sep. 1991, doi: 10.1287/isre.2.3.192.

[38] P. K. Mowbray, A. Wilkinson, and H. H. M. Tse, “An Integrative Review of Employee Voice: Identifying a Common Conceptualization and Research Agenda: Employee Voice: Review and Research Agenda," International Journal of Management Reviews, vol. 17, no. 3, pp. 382-400, Jul. 2015, doi: 10.1111/ijmr.12045.

[39] J. P. Near and M. P. Miceli, "Organizational Dissidence: The Case of Whistle-Blowing," Journal of Business Ethics, vol. 4, no. 1, pp. 1-16, Feb. 1985.

[40] P. O'Kane, O. Hargie, and D. Tourish, Key Issues in Organizational Communication. London; New York: Routledge, 2004.

[41] S. Petter, D. Straub, and A. Rai, "Specifying Formative Constructs in Information Systems Research," MIS Quarterly, vol. 31, no. 4, pp. 623-656, 2007, doi: $10.2307 / 25148814$.

[42] C. Ringle, S. Wende, and J.-M. Becker, SmartPLS 3. Bönningstedt: SmartPLS, 2015.

[43] K. Ruck, M. Welch, and B. Menara, "Employee voice: An antecedent to organisational engagement?," Public Relations Review, vol. 43, no. 5, pp. 904-914, Dec. 2017, doi: 10.1016/j.pubrev.2017.04.008.

[44] N. Shahinpoor and B. Matt, "The Power of One: Dissent and Organizational Life," Journal of Business Ethics, vol. 74, no. 1, pp. 37-48, Aug. 2007, doi: 10.1007/s10551-0069218-y.

[45] J. W. Treem and P. M. Leonardi, "Social Media Use in Organizations: Exploring the Affordances of Visibility, Editability, Persistence, and Association," Annals of the International Communication Association, vol. 36, no. 1, pp. 143-189, Jan. 2013, doi: 10.1080/23808985.2013.11679130.

[46] L. Van Dyne, J. W. Graham, and R. M. Dienesch, "Organizational Citizenship Behavior: Construct Redefinition, Measurement, and Validation.," Academy of Management Journal, vol. 37, no. 4, pp. 765-802, Aug. 1994, doi: $10.2307 / 256600$.

[47] L. Van Dyne and J. A. LePine, "Helping and voice extra-role behaviors: Evidence of construct and predictive validity.," Academy of Management Journal, vol. 41, no. 1, pp. 108-119, Feb. 1998, doi: 10.2307/256902.

[48] D. Wakabayashi, "Google Fires Engineer Who Wrote Memo Questioning Women in Tech," The New York Times, Jan. 20, 2018.

[49] M. Zaveri, "An Amazon Vice President Quit Over Firings of Employees Who Protested," The New York Times, May 04, 2020.

[50] IPA (Involvement and Participation Association). Rethinking Voice for Sustainable Business Success. Londa: IPA, 2011.
[51] "Employee-Activism-in-the-Age-of-PurposeFINAL.pdf." Accessed: Jul. 14, 2020. [Online]. Available: http://www.krcresearch.com/wpcontent/uploads/2019/06/Employee-Activism-in-the-Ageof-Purpose-FINAL.pdf. 